\title{
PEMBINAAN KARAKTER SISWA MELALUI BIMBINGAN KONSELINGDI SMAN 1 PAPAR KEDIRI
}

\author{
Wawan Setyo Budi \\ Sekolah Menengah Atas Negeri Papar Kediri \\ wsbudi@gmail.com
}

\begin{abstract}
Abstrak.
Bimbingan dan konseling di sekolah diselenggarakan untuk memfasilitasi perkembangan peserta didik/konseli agar mampu mengaktualisasikan potensi dirinya atau mencapai perkembangan secara optimal. Semua peserta didik/konseli berhak mendapatkan layanan bimbingan dan konseling agar potensinya berkembang dan teraktualisasi secara positif. Meskipun demikian, paradigma perkembangan tidak mengabaikan layanan-layanan yang berorientasi pada pencegahan timbulnya masalah (preventif) dan pengentasan masalah (kuratif). Upaya mewujudkan potensi peserta didik/konseli menjadi kompetensi dan prestasi hidup memerlukan sistem layanan pendidikan integratif. Kompetensi hidup ditumbuhkan secara isi-mengisi atau komplementer antara guru bimbingan dan konseling atau konselor dengan guru mata pelajaran dalam satuan pendidikan. Pelayanan dan bimbingan konseling pada umumnya mengemban sejumlah fungsi. Fungsi pelayanan bimbingan dan konseling khususnya di sekolah dan di madrasah memiliki beberapa fungsi, yaitu (a) fungsi pencegahan (b) pemahaman (c) pengentasan (d) pemeliharaan (e)penyaluran (f) penyesuaian (g) pengembangan dan (h) perbaikan, serta (i)advokasi. Hasil penelitian melalui deskripsi yang terdapat di dalamnya selanjutnya diformulasikan dengan teori yang ada dan relevan untuk dapat mengetahui keadaan dari pembinaan pendidikan karakter siswa melalui bimbingan konseling di SMAN 1 Papar Kediri,yang berhubungan erat dengan pengelolaannya dalam pembinaan karakter siswa dari berbagai aspek perencanaan,pelaksanaan dan evaluasinya. Selanjutnya secara detail dan sistematis dapat di ketahui faktor-faktor apa saja yang menjadi pendukung dan penghambat pembinaan karakter siswa dan pelaksanaan pembinaan karakter siswa di SMAN 1 Papar Kediri
\end{abstract}

\section{Kata kunci: Pembinaan, Bimbingan Konseling, Karakter Siswa}

\section{Pendahuluan}

Depdiknas tahun 2008 menetapkan bahwa pendidikan yang bermutu, efektif dan ideal adalah yang mengintegrasikan tiga bidang kegiatan utamanya secara sinergi,yaitu bidang administratif dan kepemimpinan, bidang instruksional atau kurikuler serta bidang bimbingan dan konseling. Lebih lanjut dijelaskan bahwa, pendidikan yang hanya melaksanakan bidang administratif dan instruksional dengan mengabaikan bidang bimbingan dan konseling hanya akan menghasilkan konseli yang pintar dan trampil dalam aspek akademik, tetapi kurang memiliki kemampuan atau kematangan dalam aspek kepribadian.

Bimbingan dan konseling di sekolah diselenggarakan untuk mem-fasilitasi perkembangan peserta didik/ konseling agar mampu mengaktualisasikan potensi dirinya atau mencapai perkem-bangan secara optimal. Fasilitasi dimaksudkan sebagai upaya memperlancar proses perkembangan peserta didik/konseli, karena secara kodrati setiap manusia berpotensi tumbuh dan berkembang untuk mencapai kemandirian secara optimal.

Bimbingan dan konseling menggunakan paradigma perkembangan individu, yang menekankan pada upaya 
mengembangkan potensi-potensi positif individu. Semua peserta didik/konseli berhak mendapatkan layanan bimbingan dan konseling agar potensinya berkembang dan teraktualisasi secara positif. Meskipun demikian, paradigma perkembangan tidak mengabaikan layanan-layanan yang berorientasi pada pencegahan timbulnya masalah (preventif) dan pengentasan masalah (kuratif).

Upaya mewujudkan potensi peserta didik/konseli menjadi kompetensi dan prestasi hidup memerlukan sistem layanan pendidikan integratif. Kompetensi hidup ditumbuhkan secara isi-mengisi atau komplementer antara guru bimbingan dan konseling atau konselor dengan guru mata pelajaran dalam satuan pendidikan.

Setiap peserta didik/konseli memiliki potensi (kecerdasan, bakat, minat, kepribadian, kondisi fisik), latar belakang keluarga, serta pengalaman belajar yang berbeda-beda. Hal ini menyebabkan peserta didik/konseli memerlukan layanan pengembangan yang berbeda-beda pula.

Perkembangan peserta didik/ konseling tidak lepas dari pengaruh lingkungan, baik fisik, psikis maupun sosial. Sifat yang melekat pada lingkungan adalah perubahan. Perubahan yang terjadi dalam lingkungan dapat mempengaruhi gaya hidup warga masyarakat, termasuk peserta didik/konseli. Pada dasarnya peserta didik/konseli SMA memiliki kemampuan menyesuaikan diri, baik dengan diri sendiri maupun lingkungan.

Proses penyesuaian diri akan optimal jika difasilitasi oleh pendidik, termasuk guru bimbingan dan konseling atau konselor. 1Penyesuaian diri yang optimal mendorong peserta didik/konseli mampu menghadapi masalah-masalah pribadi, sosial,belajar dan karir.

Kaitan layanan bimbingan dan konseling dengan aspek pengajaran dan pembelajaran di sekolah identik dengan kurikulum yang ada, di mana tujuannya adalah menyediakan pengalaman belajar bagi siswa.Bidang pengajaran menangani kurikulum pengajaran yaitu seluruh

1Zakiah Daradjat, dkk., Ilmu Pendidikan Islam, (Jakarta: Bumi Aksara, 2007), h. 28. pengalaman belajar yang di peroleh melalui segala bidang studi yang di sajikan. Nana Syaodih Sukmadinata menyatakan sebagai berikut.

"Kurikulum dan pengajaran disusun dan dilaksanakan agar para pesertadidik memiliki pengetahuan, kecakapan, dan ketrampilan secara optimal, mencapai tahap perkembangan nilai, motivasi, dan karakteristik pribadisecara optimal pula. ${ }^{2}$ Bimbingan dan konseling dirancang dan diimplementasikan agar para peserta didik berada dalam kondisi primasecara emosional dan sosial.

Peserta didik dapat terlepas dari kendala-kendala masalah pribadi san sosial, memiliki pribadi yang sehat sehinggamampu melihat diri dan lingkungannya secara obyektif, merancang danmengambil keputusan yang tepat, perkembangan optimal dapat tercapai." Dengan masukan dari bimbingan dan konseling, kurikulum bisa menjadilebih personal bagi siswa.

Bimbingan dan konseling juga dapat membantu peningkatan aspek pengajaran dan pembelajar dalam hal pengembangan kurikulum (agar sesuai dengan kebutuhan dan kapabilitas siswa) dan juga dalam menentukan penjurusan siswa, terutama dalam penjurusan siswa tidak ${ }^{2}$ hanyadidasarkan pada hasil tes IQ semata, tetapi juga memperhitungkan aspek minat, bakat, psikologis, dan kompetensi siswa.

Pada penyelenggaraan pendidikan di SMA, guru bimbingan dan konseling atau konselor berperan membantu tercapainya perkembangan pribadi, sosial, belajar, dan karir peserta didik/konseli. Pada jenjang ini, guru bimbingan dan konseling atau konselor menjalankan semua fungsi bimbingan dan konseling yaitu fungsi pemahaman, fasilitasi, penyesuaian, penyaluran, adaptasi, pencegahan, perbaikan, advokasi, pengembangan, dan pemeliharaan.

Meskipun guru bimbingan dan konseling atau konselor memegang peranan kunci dalam sistem bimbingan dan

${ }^{2} \mathrm{Abu}$ Ahmadi dan Nur Uhbiyati, Ilmu Pendidikan, (Jakarta: Rineka Cipta, 2005), h. 26. 
konseling di sekolah, dukungan dari kepala sekolah sangat dibutuhkan. Sebagai penanggung jawab pendidikan di sekolah, kepala sekolah bertanggung jawab atasterselenggaranya layanan bimbingan dan konseling. Selain itu, guru bimbingan dan konseling atau konselor sekolah harus berkolaborasi dengan pemangku kepentingan lain seperti guru bidang studi, wali kelas, komite sekolah, orang tua peserta didik, dan pihak-pihak lain yang relevan.

Dengan demikian seorang guru bimbingan dan konseling sebagai pelaksanaan dari layanan bimbingan dan konseling itu sendiri dituntut untuk memberikanlayanan semaksimal mungkin sesuai dengan kebutuhan para siswa dan semua ituuntuk mencapai kebahagiaan hidup di dunia dan akhirat. Dalam penelitian ini penulis ingin meneliti tentang layanan bimbingan dan konseling yang diterapkan di sekolah. Dalam hal ini, lembaga yang akan menjadi obyek penelitian adalah SMA 1 PAPAR.

Fokus penelitian ini dibagi menjadi dua yaitu 1) Bagaimana proses pelaksanaan pembinaan karakter siswa melalui layanan bimbingan konseling di SMAN 1 Papar Kediri, dan 2) Faktor pendukung dan penghambat pembinaan karakter siswa melalui bimbingan konseling yang diterapkan di SMAN 1 Papar Kediri ?

\section{Bimbingan dan Konseling}

Bimbingan dan konseling adalah pelayanan bantuan untuk peserta didik, baik secara perorangan maupun kelompok agar mandiri dan bisa berkembang secara optimal, dalam bimbingan pribadi, sosial, belajar maupunkarier melalui berbagai jenis layanan dan kegiatan pendukung berdasarkannorma-norma yang berlaku (SK Mendikbud No. 025/D/1995).

Bimbingan dan konseling merupakan upaya proaktif dan sistematik dalam memfasilitasi individu mencapai tingkat perkembangan yang optimal, pengembangan perilaku yang efektif, pengembangan lingkungan, dan peningkatan fungsi atau manfaat individu dalam lingkungannya. Semua perubahan perilaku tersebut merupakan proses perkembangan individu, yakniproses interaksi antara individu dengan lingkungan melalui interaksi yang sehat dan produktif. Bimbingan dan konseling memegang tugas dan tanggung jawab yang pentinguntuk mengembangkan lingkungan, membangun interaksi dinamis antara individu dengan lingkungan, membelajarkan individu untuk mengembangkan, merubah dan memperbaiki perilaku. Bimbingan dan konseling bukanlah kegiatan pembelajaran dalam konteks adegan mengajar yang layaknya dilakukan guru sebagai pembelajaran bidang studi, melainkan layanan ahli dalam konteks memandirikan peserta didik. Merujuk pada UU No. 20/2003 tentang Sistem Pendidikan Nasional, sebutan untuk guru pembimbing dimantapkan menjadi 'Konselor." Keberadaan konselor dalam sistem pendidikan nasional dinyatakan sebagai salah satu kualifikasi pendidik, sejajar dengan kualifikasi guru, dosen, pamong belajar, tutor, widyaiswara, fasilitator dan instruktur (UU No. 20/2003, pasal 1 ayat 6).Pengakuan secara eksplisit dan kesejajaran posisi antara tenaga pendidik satudengan yang lainnya tidak menghilangkan arti bahwa setiap tenaga pendidik, termasuk konselor, memiliki konteks tugas, ekspektasi kinerja, dan setting layanan spesifik yang mengandung keunikan dan perbedaan.

\section{Fungsi bimbingan dan konseling.}

Pelayanan dan bimbingan konseling pada umumnya mengemban sejumlah fungsi. ${ }^{4}$ Fungsi pelayanan bimbingan dan konseling khususnya di sekolah dan di madrasah memiliki beberapa fungsi, yaitu (a) fungsi pence-gahan (b) pemahaman (c) pengentasan (d) pemeliharaan (e) penyaluran (f) penye-suaian (g) pengembangan dan (h) perbaikan, serta (i) advokasi.

\section{Tujuan Bimbingan Konseling Islam}

Bimbingan Konseling dilakukan dengan tujuan membantu peserta didik 
dalam memahami diri sendiri, baik sebagai makhluk Tuhan maupun sebagai makhluk sosial. Menurut Samsul Munir Amin, secara rinci bimbingan konseling Islam memiliki beberapa tujan, diantaranya sebagai berikut.

a. Untuk menghasilkan suatu perubahan, perbaikan, kesehatan, dan kebersihan jiwa dan mental. Jiwa menjadi tenang, jinak dan damai (muthmainnah), bersikap lapang dada (radhiyah), dan mendapatkan pencerahan taufik dan hidayah Tuhannya (mardhiyah)

b. Untuk menghasilkan suatu perubahan, perbaikan, dan kesopanan,tingkah laku yang dapat memberikan manfaat, baik pada dirisendiri,lingkungankeluarga,lingkungan kerja, maupunlingkungan sosial dan alam sekitarnya.

c. Untuk menghasilkan kecerdasan rasa (emosi) pada individu sehingga muncul dan berkembang rasa toleransi, kesetiakawanan, tolong-monolong, dan rasa kasih sayang.

d. Untuk menghasilkan kecerdasan spiritual pada individu sehingga muncul dan berkembang rasa keinginan untuk berbuat taat kepada Tuhannya, ketulusan mematuhi segala perintah-Nya, serta ketabahan menerima ujian-Nya.

e. Untuk menghasilkan potensi ilahiah, sehingga dengan potensi itu individu dapat melakukan tugasnya sebagai khalifah dengan baik dan benar, ia dengan baik menaggulangi berbagai persoalan hidup,dan dapat memberikan kemanfaatan dan keselamatan bagi lingkungannya pada berbagai aspek kehidupan.

Berdasarkan beberapa tujuan yang telah disebutkan diatas, tujuan dari bimbingan konseling Islam pada umumnya diharapkan mampu merubah dan membantu peserta didik menjadi pribadi yang lebih baik dan berakhlakul karimah sehingga mereka dapat melaksanakan tujuan hidup di dunia menjadi khalifhah dan mendapatkan kesejahteraan didunia dan akhirat.

\section{Program Bimbingan Konseling}

a. Program bimbingan dan konseling dalam bidang pendidikan Kompleksnya permasalahan dalam bidang pendidikan, bimbingan dan konseling diperlukan bagi peserta didik agar mereka mampu mengatasi kesulitan terkait masalah dari dalam individu mereka, lingkungan maupun kesulitan yang mereka hadapi di dunia pendidikan.

\section{Perilaku Siswa}

Menurut Watson,dalam bukunya Purwa Atmaja Prawira mengatakan bahwa lingkungan merupakan faktor terpenting dibanding dengan dengan faktor-faktor keturunan dalam menentukan tingkah laku.Menurut penjabaran diatas, dapat dilihat bahwa faktor lingkungan merupakan salah satu foaktor utama dalam mempengaruhi perilku seseorang.Dalam hal ini terdapat teori tentang perilaku yang cukup popular dimana lingkungan mempengaruhi perilaku dari seseorang. Teori tersebut diantaranya:

\section{a. Teori Nativisme}

Aliran ini berpendapat bahwa segala perilaku manusia ini telah ditentukan oleh faktor-faktor yang dibawa sejak lahir.Pembawaan yang telah terdapat pada waktu dilahirkan itulah yang menentukan hasil perkembangannya. Menurut Nativisme, pendidikan tidak dapat mengubah sifat-sifat pembawaan.

\section{b. Teori Empirisme}

Aliran ini mempunyai pendapat yang berlawanan dengan kaum Nativisme. Mereka berpendapat bahwa dalam perilaku anak menjadi manusia dewasa itu sama sekali ditentukan oleh lingkungannya atau oleh pendidikan dan pengalaman yang diterimanya sejak kecil. Manusia-manusia dapat dididik menjadi apa saja (ke arah yang baik maupun ke arah yang jelek) menurut kehendak lingkungan atau pendidik-pendidiknya.

\section{c. Teori Konvergensi}

Teori ini berasal dari ahli psikologi bangsa Jerman bernama William Sterm.Ia berpendapat bahwa pembawaan dan lingkungan kedua-duanya menentukan perilaku manusia. Selain dari faktor lingkungan yang telah di jabarkan diatas 
terdapat faktor yang mempengaruhi perilaku dari seseorang diantaranya yaitu faktor keturunan dan faktor kematangan. Keturunan, pembawaan atau heredity merupakan segala ciri, sifat,potensi dan kemampuan yang dimiliki individu karena kelahirannya. Ciri, sifat dan kemampuankemampuan tersebut dibawa individu dari kelahirannya, dan diterima sebagau keturunan dari orang tuanya, dimulai dari masa manusia sebelum lahir sampai manusia dilahirkan kedunia.Ciri, sifat dan kemampuan manusia mulai dibentuk dari masa konsepsi dimana masa pertemuan antara sel dari ayah dan sel dari ibu yang kemudian berlanjut ke masa antara pembuahan dan pembelahan sel yang merupakan saat perpaduan dan penurunan sifat-sifat.Hal hal yang diturunkan pada masa konsepsi barulah berupa potensipotensi, bakal-bakal sesuatu atau sesuatu yang masih kuncup, yang perlu dikembangkan sampai manusia itu lahir di dunia dan mengenal lingkuangan yang luas.

Terdapat faktor penting disamping pembawaan dan lingkungan lainnya yang berpengaruh terhadap perkembangan individu.Yaitu faktor kematangan. Meskipun seorang anak memiliki pembawaan yang hebat dan dibesarkan dalam lingkungan yang baik tetapi apabila sesuatau aspek belum matang atau belum siap berkembang, maka tidak akan terjadi perkembangan.

Kesimpulan dari beberapa uraian diatas yaitu bahwa terdapat banyak faktor yang mempengaruhi perilaku dari seseorang baik itu internal maupun eksternal.Faktor internal yang mempengaruhi diantaranya ada faktor lingkungan dan kematangan dan faktor eksternal yaitu faktor lingkungan.

Agama merupakan bagian yang cukup penting dalam jiwa siswa.Sebagian orang berpendapat bahwa "moral dan agama dapat mengendalikan tingkah laku anak yang beranjak pada usia remaja sehingga mereka tidak akan melakukan halhal yang merugikan kepada masyarakat atau bertentangan dengan norma-norma agama".
Bimbingan konseling Islami adalah proses pemberian bantuan terarah, kontinu dan sistematis kepada setiap individu agar ia dapar mengembangkan potensi atau fitrah beragama yang dimilikinya secara optimal dengan cara menginternalisasikan nilai-nilai yang terkandung di dalam AlQuran dan Hadist rasulullah SAW. Kedalam dirinya, sehingga ia dapat hidup selaras dan sesuai dengan tuntunan al-Quran dan Hadist.Perilaku siswa merupakan merupakan reaksi atu tanggapan seseorang terhadap rangsangan dari luar maupun dari dalam dirinya yang terlahir menjadi perbuatan yang dilakukan seseorang baik itu perbuatan positif ataupun negative yang dapat diamati oleh dirinya sendiri maupun orang lain. Perilaku siswa dalam penelitian ini terbatas pada perilaku individu dan perilaku sosial siswa.

Bimbingan Konseling Islam mempunyai fungsi, tujuan dan program yang berkaitan dengan pengembangan perilaku yang mencangkup individu siswa yang mempunyai harapan untuk membentuk perilaku individu siswa menjadi lebih baik lagi dan berkarakter.

Bimbingan konseling islam selain mempunyai fungsi, tujuan dan program untuk perilaku sosial siswa, bimbingan konseling Islam ini pun mempunyai fungsi, tujuan dan program untuk membantu siswa untuk mempunyai kemampuan sosial untuk bersosialisai kepada lingkungan sekitarnya, yaitu kepada teman, guru dan orang tua.

\section{Metode Penelitian}

Metode penelitian ini menggukan pendekatan penelitian kualitatif.Adapun metode penggalian datanya dengan metode obervasi, interview, dan dokumentasi. Sedangkan analisis datanya menggunakan analisis kualitatif dari Miles dan Hubberman, yaitu dengan tiga tahapan, yakni 1) reduksi data (data reduction), 2) penyajian data (data displays dan 3) penarikan kesimpulan/ verifikasi (conclusion drawing/veriffication). 


\section{Hasil Penelitian}

\section{Peran Bimbingan Konseling dalam Pembinaan Karakter Siswa.}

Melalui segenap data dan keterangan-keterangan dari hasil penelitian yang mendeskripsikan kondisi di lapangan dari pengelolaan pembinaan karakter siswa melalui bimbingan konseling yang dilakukan oleh segenap pemangku kepentingan dan warga sekolah dapat diformulasikan maknanya, sehingga melalui permaknaan itu dapat memberikan arti terhadap rumusan masalah dalam penelitian ini. Hasil penelitian melalui deskripsi yang terdapat di dalamnya selanjutnya diformulasikan dengan teori yang ada dan relevan untuk dapat mengetahui keadaan dari pembinaan pendidikan karakter siswa melalui bimbingan konseling di SMAN 1 PAPAR KEDIRI,yang berhubungan erat dengan pengelolaannya dalam pembinaan karakter siswa dari berbagai aspek perencanaan, pelaksanaan dan evaluasinya. Segenap data dan keterangan tersebut bisa menjelaskan secara umum bagaimana pengelolaan pembinaan karakter siswa melalui bimbingan konseling di SMAN 1 PAPAR. Selanjutnya secara detil dan sistematis segenap data dan keterangan tersebut meliputi: (1) Pelaksanaan pembinaan karakter siswa di SMAN 1 PAPAR KEDIRI, (2) Faktor pendukung dan penghambat pembinaan karakter siswa melaui bimbingan konseling di SMAN 1 PAPAR KEDIRI.

\section{Faktor Pendukung dan Faktor Penghambat Pembinaan karakter siswa.}

Secara umum faktor pendukung kegiatan Pembinaan karakter siswa melalui bimbingan konseling di SMAN 1 PAPAR KEDIRI,adalah :

1. SMAN 1 PAPAR KEDIRI berkembang dengan baik melalui budaya sekolah yang mendukung. Pembentukan budaya sekolah (school culture) sebagai faktor pendukung pebinaan karakter siswa di SMAN 1 PAPAR dilakukan melalui serangkaian kegiatan: perencanaan, pelaksanaan pembelajaran yang lebih berorientasi pada peserta didik, dan penilaian yang bersifat komprehensif.

2. Perencanaan di tingkat sekolah adalah melakukan penguatan dalam penyusunan kurikulum di tingkat sekolah (KTSP), seperti menetapkan visi, misi, tujuan, struktur kurikulum, kalender akademik, penyusunan silabus dan rencana pelaksanaan pembelajaran (RPP).Keseluruhan perencanaan sekolah yang bertitik tolak dari melakukan analisis kekuatan dan kebutuhan sekolah ternyata dapat menghasilkan program pendidikan yang lebih terarah yang tidak sematamata berupa penguatan ranah pengetahuan dan keterampilan melainkan juga sikap perilaku yang akhirnya dapat membentuk akhlak budi luhur melalui bimbingan konseling yang di ajarkan di dalam kelas.

3. Penerapan pembinaan karakter dengan pendekatan belajar aktif juga memperoleh dukungan berupa kebijakan, dana, pelatihan, sarana dan prasarana dari komite satuan pendidikan, Dunia usaha/Dunia industri (Du/Di), masyarakat sekitar, orang tua peserta didik, alumni, dan pemerintah daerah; Berdasarkan hasil penelitian yang dilakukan di SMAN 1 PAPAR KEDIRI hampir tidak memiliki hambatan-hambatan yang berarti. Beberapa hambatan secara mikro yaitu; (1) hanya terjadi pada kegiatan bersalaman pada pagi hari,dimana beberapa guru yang memperoleh tugas kadang-kadang hadir setelah pukul 07.15 pagi sedemikian guru yang bersangkutan kurang dapat menyalami peserta didik yang datang sebelum pukul 07.15 pagi, karena berdasarkan pengamatan hampir sebagian besar peserta didik datang tepat waktu 15 menit sebelum kegiatan pembelajaran dimulai; (2) kehadiran beberapa guru piket yang terkadang hadir diantara pukul 07.15 samapai 07.30, padahal seharusnya guru piket harus hadir pukul 07.00 sesuai komitmen yang telah disepakati sekolah sehingga kontribusinya terhadap ketertiban dan 
kedisiplinan serta pelayanan terhadap sekolah pada kegiatan awal sebelum dilaksanakan pembelajaran pada jam pertama menjadi kurang optimal; (3) ketika proses pembacaan doa di awal kegiatan pembelajaran dan di akhir pembelajaran yang hanya dilakukan oleh guru agama, terkadang kurang efisien, mengingat kesibukan jam mengajar guru agama yang cukup tersebar yaitu mengajar pada jam pertama dan pada jam terakhir; dan (4) Hampir setiap hari masih ditemui beberapa peserta didik yakni sekitar satu sampai tiga orang yang terlambat karena alasan yang cukup beragam misalnya karena bangun kesiangan, macet, jarak rumah yang terlalu jauh dengan sekolah dan lain sebagainya yang secara realistis alasan yang disampaikan masih realistis.(5)Sumber Daya Manusia dari guru Bimbingan dan Konseling masih perlu di tingkatkan kompetensinya agar dapat mencapai hasil yag optimal lagi dalam membina karakter siswa di SMAN 1 PAPAR KEDIRI.

\section{Pelaksanaan Pembinaan Karakter siswa.}

Pendidikan karakter menjadi kebutuhan mendasar bagi masyarakat. ${ }^{3}$. Berdasarkan hasil penelitian yang telah dilakukan peneliti, pembinaan karakter sisa itu meliputi perumusan visi, misi, tujuan dan struktur kurikulum. Sekolah menyusun perencanaan pembinaan karakter siswa berdasarkan analisis kebutuhan dan analisis konteks yang melibatkan warga sekolah dan pemangku kepentingan. Para orang tua wali murid membina hubungan yang baik dengan BK yang ada di SMAN 1 Papar.Agar segala macam permasalahan tentang siswa Di SMAN 1 Papar Kediri dapat di selesaikan dengan baik.Di tahun berikutnya diharapkan dapat lebih meningkatkan kualitas penyelenggaraan pembinaan karakter siswa di sekolah.

Mengenai perumusan tujuan pembinaan karakter siswa dan struktur kurikulum,bahwa sekolah di SMAN 1 PAPAR KEDIRI memiliki program khusus

3 Jauhar Fuad, "Pendidikan Karakter Dalam Pesantren Tasawuf," Jurnal Pemikiran Keislaman 23, dan struktur kurikulum dalam perumusan pembinaan karakter siswa melalui bimbingan konseling. Hal ini terbukti karena berdasarkan hasil penelitian mengatakan bahwa di SMAN 1 PAPAR KEDIRI memfasilitasi peserta didik agar menjadi manusia yang beriman dan bertaqwa kepada Tuhan Yang Maha Esa, berakhlak mulia, sehat, berilmu,cakap, kreatif, mandiri, dan menjadi warga negara yang demokratis serta bertanggung jawab. Juga, struktur kurikulum, sesuai dengan kondisi yang ada telah memuat pembinaan karakter siswa melalui bimbingan konseling dengan memuat kegiatan yang dapat memfasilitasi peserta didik untuk menjadi manusia yang beriman dan bertaqwa kepada Tuhan Yang Maha Esa serta berakhlak mulia. Akhlak mulia mencakup etika, budi pekerti, atau moral sebagai perwujudan dari pendidikan agama. Keseluruhan dari program perencanaan itu diorientasikan terhadap proses dan hasil produk belajar. Menurut Kesuma dkk (2011: 40) pendidikan karakter dalam sekolah dapat berorientasi proses, yaitu asal para siswa mengalami kegiatan tertentu yang direncanakan sekolah, dan dapat pula berorientasi hasil atau produk belajar. Para siswa yang hasil belajaranya belum sesuai standar yang ditetapkan harus dibimbng secara khusus. Perencanaan harus sedemikian rupa agar intensitas/kualitas proses dapat dicapai hingga semua siswa diharapkan mengalami perubahan tingkah laku.Dari hasil penelitian dan pembahasan yang dilakukan, bahwa pembinaan karakter siswa melalui bimbingan konseling di SMAN 1 Papar Kediri telah di terapkan dan di gunakan. SMAN 1 Papar Kediri dulunya merupakan sekolah yang tidak begitu dikenal oleh masyarakat. Dengan kerja keras dan peran guru serta karyawan di sekolah itu, mampu membuat SMAN 1 Papar Kediri berkembang menjadi sekolah yang penuh prestasi. Karena output pendidikan merupakan hasil kolektif warga seklah, antara individu dalam sekolah harus merupakan kebiasaan sehari-hari warga

no. 1 (February 28, 2013), http://ejournal.iaitribakti.ac.id/index.php/tribakti/article/view/13 
sekolah, seiring dengan peningkatan prestasi yang diperoleh SMAN 1 Papar Kediri dari tahun ke tahun akhirnya masyarakat menjadi lebih percaya.

Dalam upayanya meningkatkan program pembinaan karakter siswa ini Kepala Sekolah dan guru BK beserta para guru bertindak sebagai tenaga pelaksana inti prgram. Sejalan dengan pembinaan mental siswa, maka sekolah dituntut untuk mampu merancanakan, melaksanakan dan mengevaluasi serta mempertanggungjawabkan pengelolaan sekolah secara jujur kepada masyarakat setempat.

Pertanggungjawaban dapat dilakukan dengan melalui pertemuan dan rapat koordinasi dengan dewan sekolah dengan memaparkan secara terbuka semua persoalan sekolah, khususnya masalah sekolah. Untuk meningkatkan profesionalisme guru, perlu ditingkatkan melalui dengan mengikutkan penataran-penataran, yang dimaksud dengan penataran ialah semua usaha pendidikan dan pengalaman untuk meningkatkan keahlian guru dan pegawai guna menyelamatkan pengetahuan dan keterampilan mereka dengan kemajuan dan perkembangan ilmu pengetahuan dalam bidang masing-masing. Dalam hal ini sesuai dengan penjelasan oleh kepala sekolah "dengan biaya lembaga, pihak sekolah akan mengusahakan pada setiap pendidikan untuk diikutkan MGMP yang dapat meningkatkan wawasan dan kemapuan mereka dalam mendidik khususnya dalam pendidikan agama islam yang dilaksanakan setiap bulan sekali" Tujuan dari pada penataran ini adalah mempertinggi mutu para petugas dalam bidang prfesinya masing-masing meningkatkan efesiensi kerja menuju kearah tercapainya hasil yang optimal dan mengembangkan kegairahan kera dan meningkatkan kesejahteraan guru.

\section{Menciptakan suasana sekolah yang religious}

Usaha yang dilakukan diantaranya membuka dan menutup pelajaran dengan salam, semua dewan guru beserta siswa setiap harinya mengenakan seragam berjilbab, mewajibkan siswa memakai pakaian yang menutup aurat sesuai dengan syari'at Islam begitu juga guru, menempelkan beberapa kaligrafi di dinding agar mudah dibaca, dan membiasakan siswa bersikap tawadhu' (rendah hati). Sebelum pelajaran dimulai siswa membaca Asmaul Husna, dan setiap hari Jum'at pagi siswa melakukan kegiatan rutin yaitu beramal dengan mengisi kotak amal di kelas masing-masing yang dipandu guru kelasnya. Dengan kegiatan-kegiatan tersebut, memang terasa sekali suasana religious di SMAN 1 Papar Kediri.Lingkungan yang Islami seperti ini sangat efektif untuk membentuk akhlak mulia pada diri siswa.

1) Memberikan tausyiah (wasiat dengan ketaqwaan)

Dalam sebuah hadits Rosululloh memrintahkan kepada kita untuk mengikuti setiap kesalahan dan dosa yang kita lakukan dengan kebaikan yang pasti akan menghapuskan dosa dan kesalahan tersebut. Tausyiah adalah salah satu cara yang efektif untuk mengingatkan warga sekolah termasuk di dalamnya siswa untuk selalu berbuat baik dan memohon ampun kepada Allah SWT ketika melakukan dosa dan kesalahan.

2) Membiasakan anak didik untuk taat beribadah

Segala sesuatu jika dilakukan dengan kesadaran dan tidak Karena keterpaksaan, maka hasilnya akan lebih bagus. Pembiasaan adalah salah satu metode yang bagus untuk menumbuhkan kesadaran tersebut.

3) Memasukkan unsur-unsur akhlak dalam setiap materi pelajaran

Sebenarnya ilmu agama itu amat luas dan dapat menjangkau segala aspek kehidupan. Sedcara halus dan terkesan tidak menggurui cara ini amat tepat diterapakan agar anak terbiasa melihat segala sesuatu dengan kacamata agama.

4) Mengajak anak didik untuk tadabbur alam. Allah SWT telah menciptakan alam semesta ini untuk kemaslahatan hidup manusia.Keseimbangan alam 
yang luar biasa adalah bukti kebesaran Allah. Dengan cara tadabbur alam ini, siswa benar-benar dilatih untuk peka terhadap apapun ciptaan Allah yang ada di alam semesta ini. Dari bendabenda di sekitar mereka sampai bendabenda luar angkasa.Semua diatur oleh Allah tanpa cela dan cacat sedikitpun, luar biasa sempurna ciptaan Allah yang Maha sempurna.

5) Mengajak anak didik untuk peduli terhadap sesame teman

Sikap itsar (mementingkan kepentingkan kepentingan orang lain) adalah sikap yang amat mulia dan terpuji. Membiasakan sejak dini untuk selalu peduli terhadap sesame adalah sangat penting agar siswa tumbuh dalam pribadi yang tidak egois.Sikap peduli siswa ditunjukkan dengan menjenguk teman yang sakit, meringankan beban teman yang kesusahan dengan cara iuran dan lain sebagainya.

Upaya-upaya guru agama dalam pembinaan karakter siswa di SMAN 1 Papar Kediri ini ternyata sesuai dengan yang sudah dikemukakan Hal ini ditunjukkan dengan pihak sekolah yang perlu melibatkan seluruh unsur baik dari pihak sekolah (guru, staff akademik dan karyawan) maupun orang tua siswa. ${ }^{4}$

Di samping itu di SMAN 1 PAPAR KEDIRI juga menerapkan Sanksi-sanksi Akademik yaitu: 1) Penanganan pelanggaran. Penanganan Pelanggaran terhadap siswa di lakukan dengan cara bertingkat yaitu:Penanganan oleh guru piket atau sekbid, Penanganan oleh wali kelas, Penanganan oleh BK, dan Konferensi kasus.

Bentuk-bentuk sanksi yang di lakukan di SMAN 1 PAPAR KEDIRI di lakukan dengan bertingkat,berupa; Teguran, Peringatan baik lisan maupun tulisan, Hukuman yang bersifat mendidik, Home visit, Membuat pernyataan tertulis, Membuat pernyataan bermaterai 3000,di tandatangani orang tua,wali kelas dan $\mathrm{BK}$, Membuat pernyataan bermaterai 6000,di tandatangani orang tua,wali kelas,dan BK, Dikembalikan ke Orang tua.

\section{Kesimpulan}

Akhirnya penelitian ini dapat disimpulkan 1.Faktor Pendukung dan Faktor Penghambat Pembinaan karakter siswa melalui bimbingan konseling di SMAN 1 PAPAR KEDIRI.Secara umum faktor pendukung kegiatan Pembinaan karakter siswa melalui bimbingan konseling di SMAN 1 Papar Kediri,adalah a. SMAN 1 PaparKediri berkembang dengan baik melalui budaya sekolah yang mendukung. Pembentukan budaya sekolah (school culture) sebagai faktor pendukung pembinaan karakter siswa di SMAN 1 Papardilakukan melalui serangkaian kegiatan: perencanaan, pelaksanaan pembelajaran yang lebih berorientasi pada peserta didik, dan penilaian yang bersifat komprehensif. Perencanaan di tingkat sekolah adalah melakukan penguatan dalam penyusunan kurikulum di tingkat sekolah (KTSP), seperti menetapkan visi, misi, tujuan, struktur kurikulum, kalender akademik, penyusunan silabus dan rencana pelaksanaan pembelajaran (RPP). Keseluruhan perencanaan sekolah yang bertitik tolak dari melakukan analisis kekuatan dan kebutuhan sekolah ternyata dapat menghasilkan program pendidikan yang lebih terarah yang tidak sematamata berupa penguatan ranah pengetahuan dan keterampilan melainkan juga sikap perilaku yang akhirnya dapat membentuk akhlak budi luhur melalui bimbingan konseling yang di ajarkan di dalam kelas.2. Penerapan pembinaan karakter dengan pendekatan belajar aktif juga memperoleh dukungan berupa kebijakan, dana, pelatihan, sarana dan prasarana dari komite satuan pendidikan, Dunia usaha, masyarakat sekitar, orang tua peserta didik, alumni, dan pemerintah daerah; Berdasarkan hasil penelitian yang dilakukan di SMAN 1 Papar Kediri hampir tidak memiliki hambatanhambatan yang berarti.

4 Dewa Ketut Sukardi, Pengantar Pelaksanaan Program Bimbingan dan Konseling di Sekolah, (Jakarta: Rineka Cipta, 2002), h. 21. 


\section{Daftar Pustaka}

J. Moleong, Lexy. 2000, ,Metodologi Penelitian Kualitatif.Bandung: Remaja Rosdakarya.

Mulyasa, E., Manajemen Berbasis Sekolah. Bandung: PT. Remaja Rosdakarya, 2007.

Mulyono, 2010 Manajemen Administrasi \& Organisasi Pendidikan.Jogjakarta: ARRuzz Media.

M. Muliono, Anton, 2013 Kamus Besar Bahasa Indonesia. Jakarta: Balai Pustaka.

Nasution, S., 1996.Metodologi Penelitian Naturalistik Kualitatif. Bandung: Tarsito

Patttilima, Hamid, 2005. Metode Penelitian Kualitatif. Bandung: Alfabeta.

Mufid, Ahmad Syafi'i. dkk. 2000. Pendidikan Agama Islam Edisi 2.Jakarta: Yudhistira

http.www//cara_sehat_islami.com Downlo ad tgl 30 Nov 2011, jam 14.00 Wita

Nata, Abudin. 2004. Perspektif Islam Tentang Pendidikan Kedokteran Paradigma Sehat

Lomenta, Benjamin. 1989. Buku Panduan Pelayanan Kesehatan. Bandung : EGC

A.H. Markum.1991. Ilmu Kesehatan Anak. Jakarta. FKUI A.M Sugeng Budiono, 2003, Bunga Rampai Hiperkes \& KK, Semarang: Badan Penerbit Universitas Diponegoro

Achmad Dajaeni, S. 1999a. Ilmu Gizi untuk mahasiswa dan Profesi Jilid I. Jakarta

Achmad Munib, dkk, 2004, Pengantar Ilmu Pendidikan, Semarang: UPT UNNESPRESS. Achmadi.

ISPA 2010 Pembunuh Utama. Available online at http://www.ppmplp.depkes.go.id, diakses tanggal 12 April 2010

Adams, George L. 1997. BOIES" Buku Ajar Penyakit THT (BOIES Fundamentals of Otolaryngology)" F.disi 6. Jakarta: EGC(67) Al-Abrosy, Athiyah,Dasardasar Pokok Pendidikan Islam II, Jakarta: Bulan Bintang.

Al-Ghozali, 1997.Abu Hamid, Ihya' Ulumuddin, Ismail Ya'qub, Faizin.

Arifin, H.M. 1996, Ilmu Pendidikan Islam, Jakarta: Bumi Aksara
Darajat, Zakiyah, 1996. Pendidikan dalam Keluarga dan Sekolah, Jakarta: Ruhama, Pendidikan dalam Pembinaan Mental, Bulan Bintang, Jakarta, 1968.

Fajar, A. Malik, Reorientasi Pendidikan Islam, Fajar Dudia, Jakarta, 1999.

Fuad, Jauhar, "Pendidikan Karakter Dalam Pesantren Tasawuf," Jurnal Pemikiran Keislaman 23, no. 1 (February 28, 2013), http://ejournal.iaitribakti.ac.id/index.php/tribakti/articl e/view/13

Gardner, James, E., Memahami Gejolak Remaja, PT. Mitra Utama, Jakarta, 1990.

Mahjuddin, Membina Mental Anak, AlIkhlas, Surabaya, 1995.

Purwadarminto, W.J.S., Kamus Umum Bahasa Indonesia, Pusat Pustaka, Jakarta.

Rodiyah, ST., Setyowati, Nanik, Pendidikan Generasi Muda, Penerbit SIC Kerjasama LPM IKIP, Surabaya, 1996.

Rusyd, Abidin Ibnu, Pemikiran al-Ghozali tentang Pendidikan, Pustaka Pelajar, Yogyakarta, 1991.

Shahih Muslim, Daarul Fikri, Libanon. Soekanto, Soerjono, Sosiologi Keluarga, Rineka Cipta, Cet. Ke-2, Jakarta, 1992.

Tafsir, Ahmad, Ilmu Pendidikan dalam Perspektif Islam, PT. Rosdakarya, Bandung, 1991.

Zuhairini, dkk, Metode Khusus Pendidikan Agama, Usaha Nasional, Jakarta, 2004.

Zulkifli, 1986.Psikologi Perkembangan, Rosda Karya, Bandung: Remaja Rosdakarya 